\title{
Diagnosis Kerusakan Roda Gigi dengan Metode Ensemble Emperical Mode Decomposition (EEMD)
}

\author{
Eky Fortuna Pradika ${ }^{\mathrm{a}, *}$, Achmad Widodo ${ }^{\mathrm{b}}$, Ismoyo Haryanto ${ }^{\mathrm{b}}$ \\ ${ }^{a}$ Mahasiswa Program Studi S1, Departemen Teknik Mesin, Fakultas Teknik, Universitas Diponegoro \\ ${ }^{b}$ Dosen DepartemenTeknik Mesin, Fakultas Teknik, Universitas Diponegoro \\ Jl. Prof. Soedharto, SH Tembalang, Semarang 50275, Telp. +62247460059 \\ *E-mail: pekyfortuna@gmail.com
}

\begin{abstract}
Maintenance is a combination of various actions taken to maintain the performance of the engine or fix it to an acceptable condition. In the industrial world, maintenance has a huge influence on the condition of the engine and the amount of production. The use of a machine for a long time will certainly require treatment, one method of treatment is predictive treatment. The gears are a very important component in the engine, so the gears also need to be aware of their conditions to avoid damage during engine operation. Various types of damage to the gears that often occur include wear, cracks, and broken gears. To determine wear on the gears, an indicator is needed that can show the wear of the gears. This study aims to diagnose the condition of gears by using the empirical mode decomposition (EEMD) ensemble method. This article also discusses some extraction features used such as: spectrogram, RMS, kurtosis, and crest factor as a comparison. The results showed differences in the condition of gears in normal conditions, wear and broken shafts can be detected using the EEMD method by looking at the appearance of peak. In the spectrogram feature, it is clear the dark red color shows high vibrations at certain frequencies which indicate the occurrence of vibrations at that frequency.
\end{abstract}

Keywords: EEMD, wearing, maintenance, gears

\section{Abstrak}

Perawatan mesin merupakan suatu kombinasi dari berbagai tindakan yang dilakukan untuk menjaga performa mesin atau memperbaikinya sampai pada suatu kondisi yang bisa diterima. Dalam dunia industri, pemeliharaan memberikan pengaruh yang sangat besar bagi kondisi mesin dan jumlah produksi. Penggunaan mesin dalam jangka waktu lama tentunya akan membutuhkan perawatan, salah satu metode perawatan adalah perawatan prediktif. Roda gigi adalah komponen yang sangat penting pada mesin, oleh karenanya roda gigi juga perlu diperhatikan kondisinya untuk menghindari kerusakan pada saat pengoperasian mesin. Macam-macam kerusakan pada roda gigi yang sering terjadi diantaranya adalah keausan, retak, dan patah roda gigi. Untuk mengetahui keausan pada roda gigi, diperlukan adanya indikator yang dapat menunjukan keausan roda gigi. Penelitian ini bertujuan untuk mendiagnosa kondisi roda gigi dengan menggunakan metode ensemble empirical mode decomposition (EEMD). Artikel ini juga membahas tentang beberapa fitur ekstraksi yang digunakan seperti: spectrogram, RMS, kurtosis, dan crest factor sebagai pembanding. Hasil penelitian menunjukan perbedaan kondisi roda gigi pada keadaan normal, aus dan patah poros dapat dideteksi dengan menggunakan metode EEMD dengan melihat kemunculan peak. Pada fitur spectrogram terlihat jelas warna merah gelap yang menunjukan terdapatnya getaran yang tinggi pada frekuensi tertentu yang mengindikasi terjadinya getaran pada frekuensi tersebut.

Kata kunci: EEMD, keausan, pemeliharaan, roda gigi

\section{Pendahuluan}

Roda gigi atau gear adalah elemen mesin yang digunakan untuk mentransmisikan daya dan mengubah putaran poros pada mesin. Roda gigi meneruskan daya dari penggerak (semisal motor listrik) melalui kontak antar gigi-gigi pada gear dengan gigi-gigi pada pinion. Roda gigi juga digunakan untuk mengubah arah sumbu putar dan mengubah gerak rotasi menjadi translasi. Roda gigi memainkan peranan penting dalam menjalankan peralatan yang menunjang kehidupan manusia. Di dalam aplikasi penggunaan transmisi roda gigi sering dijumpai beberapa masalah, misalnya patah pada kepala roda gigi, keausan roda gigi dan timbulnya suara berisik pada roda gigi, oleh karenanya diperlukan perawatan roda gigi guna mencegah masalah yang terjadi pada transmisi roda gigi tersebut.

Sistem transmisi daya yang menggunakan roda gigi telah banyak digunakan pada berbagai jenis penggerak, putaran roda gigi akan menghasilkan gaya kontak antar gigi. Pada saat beroperasi gaya kontak tersebut dapat membuat kerusakan pada permukaan gigi yang kemudian berlanjut pada kerusakan pitting dan berujung pada kerusakan yang 
parah. Oleh karena itu diperlukan strategi perawatan yang baik untuk mengurangi kerusakan yang disebabkan kondisi operasi pada roda gigi. Walaupun sudah ada strategi perawatan yang terjadwal untuk melihat kondisi mesin, namun preventive maintenance $(\mathrm{PM})$ belum dapat menanggulangi kerusakan yang tak terduga, maka diperlukan predictive maintenance (PdM) [1]. Salah satu tindakan PdM yang biasa dilakukan adalah dengan melihat karakteristik getaran yang ditimbulkan oleh mesin karena pada umumnya sebuah mesin yang berputar pasti akan menghasilkan getaran yang nantinya getaran tersebut dapat dianalisis.

Berbagai macam metode yang dapat digunakan untuk melihat karakteristik getaran pada roda gigi. Salah satu metode yang sering digunakan untuk mengolah sinyal getaran yang dihasilkan oleh roda gigi adalah metode ensemble emperical mode decomposition (EEMD). EEMD adalah sebuah metoda signal processing yang memiliki tahapantahapan. Tahapan-tahapan tersebut dimulai dari metode emperical mode decomposition (EMD) yaitu serangkaian fungsi waktu dari serangkaian data masukan ditransformasikan menjadi sejumlah modus yang terdiri dari beberapa intrinsic mode function (IMF) dan sinyal residu, kemudian tahap yang terakhir adalah ditambahkan sinyal white noise untuk mengkompensasi modus campuran yang dapat tebentuk [2].

\section{Material dan Metodologi}

Gambar 1 memperlihatkan diagram alir penelitian yang dimulai dari studi literatur serta pengambilan data yang diperoleh dari Grenoble Images Speech Signal and Control Laboratory (GIPSA-lab), Prancis dimana pengujian diambil setiap 25 jam roda gigi beroperasi. Data yang didapat berupa data getaran domain waktu kemudian diubah menjadi domain frekuensi dengan menggunakan metode fast fourier transform (FFT). Kemudian hasil FFT tersebut dibandingkan dengan data yang diolah menggunakan metode EEMDberbasis software MATLAB R2014b. Hasil pengolahan sinyal dengan FFT tanpa-EEMD dan dengan menggunakan metode EEMD kemudian digunakan sebagai sumber tahap ekstraksi fitur statistik seperti root mean square (RMS), kurtosis, crest factor dan spectrogram.

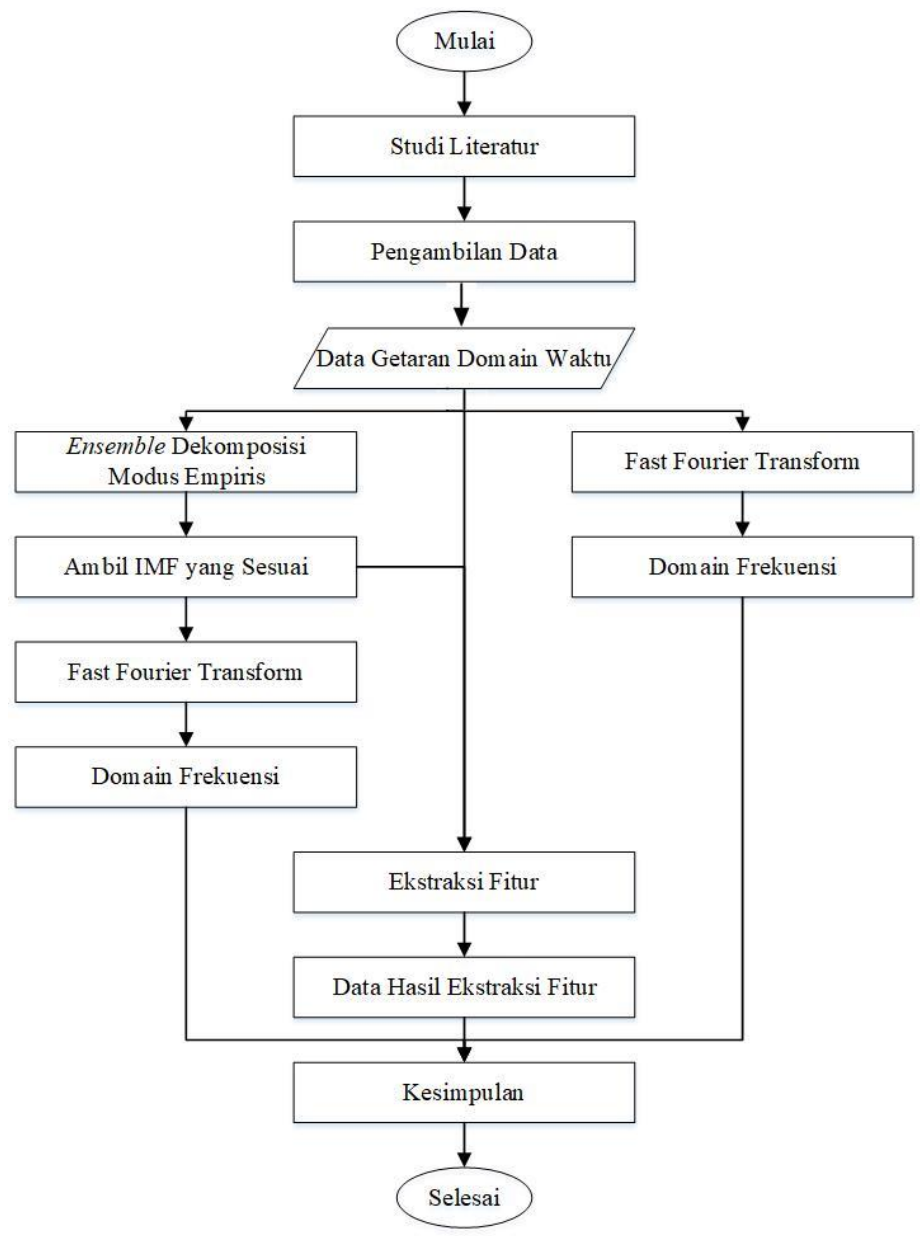

Gambar 1. Diagram alir penelitian.

Selanjutnya untuk menganalisa lebih lanjut diperlukan perhitungan nilai hunting tooth frequency (HTF) dan gear mesh frequency (GMF) untuk memastikan gejala getaran apa yang muncul, misalnya karena kondisi aus, retak, patah gigi, dan masalah lainnya. Kemudian hasil dari metode EEMD ini adalah beberapa sinyal dekomposisi yang selanjutnya dalam bentuk IMF yang selanjutnya akan dipilih dan diubah dalam bentuk sinyal domain frekuensi melalui FFT. Pada penelitian ini hanya mengambil IMF ke-1 sebagai sinyal yang akan diubah menjadi domain frekuensi. Langkah 
selanjutnya adalah proses pengolahan parameter statistik yang berupa nilai kurtosis, RMS, crest factor, dan spectrogram.

Proses selanjutnya membuat plot terhadap nilai parameter-parameter yang muncul, nilai ini diolah dari beberapa kondisi yakni kondisi normal, aus, dan kerusakan pada poros. Data parameter tesebut dibedakan dalam 2 metode pengolahan data yaitu data masih dalam domain waktu (masih belum di olah) dan setelah diproses dengan metode EEMD. Nilai sampel yang telah diambil kemudian diplot untuk melihat perbedaan kondisi roda gigi.

\subsection{Ensemble Emperical Mode Decomposition (EEMD)}

EEMD merupakan pengembangan dari EMD yang dilakukan dengan menambahkan sinyal white noise pada data runtun waktu untuk mengkompensasi terbentuknya modus campuran. Sinyal white noisemerupakan sinyal acak yang dibangkitkan dengan menggunakan frekuensi terdistribusi merata pada sepanjang data dengan rentang waktu tertentu

$$
\begin{aligned}
& x_{m}(t)=x(t)+n_{m}(t) \\
& n_{m}(t)=N_{s t d} * \operatorname{randn}(x(t))
\end{aligned}
$$

dimana $x(t)$ adalah sinyal original, $x_{m}(t)$ adalah sinyal ditambah white noise, $n_{m}(t)$ adalah jumlah white noise, $N_{\text {std }}$ adalah nilai standar deviasi, dan $\operatorname{randn}(x(t))$ adalah nilai pseudorandom yang disebar secara normal [2].

\subsection{Root Mean Square}

Root mean square (RMS) merupakan akar dari nilai rata-rata dari suatu fungsi yang dikuadratkan. RMS merupakan ciri yang dapat mengukur komposisi karakteristik energi dari sinyal getaran. Ciri ini baik dalam mengidentifikasi tingkat noise secara keseluruhan, tetapi tidak menyediakan informasi apapun tentang lokasi komponen yang rusak [4].

$$
R M S=\frac{1}{N} \sqrt{\sum_{i=1}^{N} X_{1}^{2}}
$$

\subsection{Kurtosis}

Kurtosis didefinisikan sebagai momen keempat dari distribusi dan mengukur kelancipan dan kedataran relatif sebuah distribusi dibanding distribusi normal. Kurtosis memberikan suatu pengukuran dari ukuran tail distribusi dan digunakan sebagai indikator puncak utama dalam sebuah kumpulan data. Untuk mendapatkan nilai kurtosis $(K)$

$$
K=\frac{\frac{1}{N} \sum_{t=1}^{N}\left(X_{i}-\mu\right)^{4}}{\sigma^{4}}
$$

\subsection{Crest Factor}

Crest factor adalah parameter bentuk gelombang, seperti arus bolak-balik atau suara, yang menunjukkan rasio nilai puncak dengan nilai efektif. Dengan kata lain, faktor puncak menunjukkan seberapa ekstrim puncak dalam bentuk gelombang. Crest factor menunjukkan tidak ada puncak, seperti arus searah. Faktor puncak yang lebih tinggi mengindikasikan puncak, misalnya gelombang suara cenderung memiliki faktor puncak yang tinggi [3]

$$
C F=\frac{\left|x_{\text {peak }}\right|^{2}}{x_{r m s}{ }^{2}}
$$

\subsection{Gear Mesh Frequency (GMF)}

Gear mesh frequency adalah tingkat dimana gigi-gigi pasangan bersama-sama di gearbox. Ini sama dengan jumalah gigi dikali RPM. Sebuah gearbox akan selalu memiliki komponen getaran yang kuat pada frekuensi mesh gigi dan ini adalah satu dari frekuensi gangguan yang digunakan dalam pemantauan mesin.

\subsection{Hunting Tooth Frequency (HTF)}

Frekuensi lain yang kadang-kadang digunakan adalah Hunting Tooth Frequency (HTF). Ini ditemukan ketika satu gigi pada setiap gigi rusak dan mewakili frekuensi di mana kedua gigi saling bersentuhan. Perhitungan frekuensi ini juga tergantung pada jumlah gigi per gigi dan melibatkan mencari faktor umum tertinggi (CF) antara rasio gigi.

\section{Hasil dan Pembahasan}

\subsection{Analisis Sinyal Getaran non-EEMD dan EEMD}

Sinyal asli dengan kondisi normal, aus dan patah poros yang telah diubah menjadi domain frekuensi menggunakan FFT ditunjukkan pada Gambar 2 sampai 4. 


\subsubsection{Analisis FFT pada kondisi normal}

Data getaran domain waktu dari roda gigi kondisi normal sebelum EEMD kita rubah menjadi domain frekuensi dengan mengunakan FFT dapat kita lihat pada Gambar 2 sedangkan data getaran domain waktu roda gigi kondisi normal setelah EEMD kita pilih IMF 1 untuk di FFT agar berubah menjadi domain frekuensi. Hasil plot gambar keduanya dapat kita lihat sebagai berikut

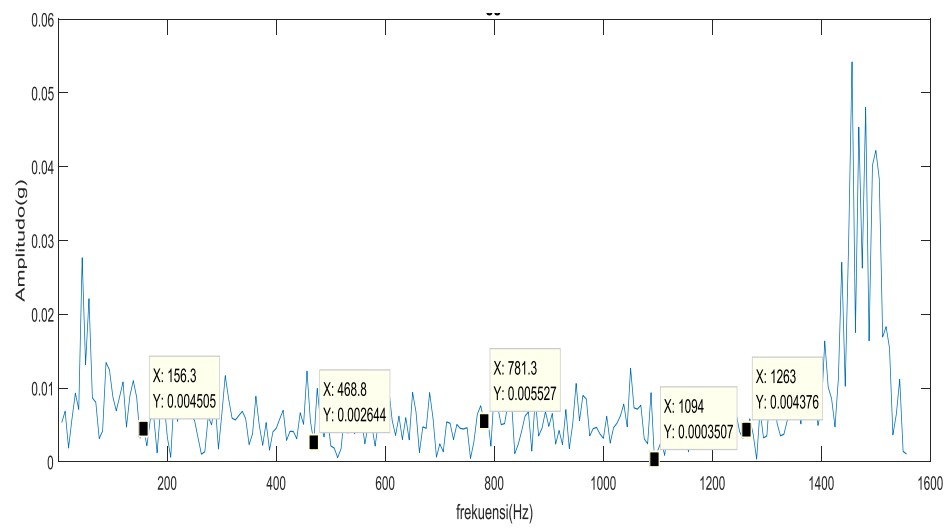

Gambar 2. FFT sinyal kondisi normal sebelum menggunakan EEMD

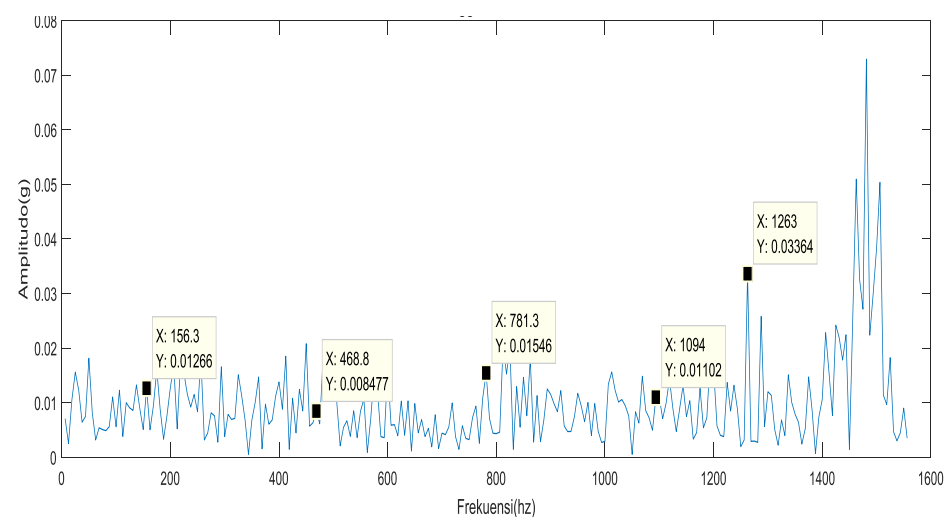

Gambar 3. FFT sinyal kondisi NORMAL setelah mengunakan metode EEMD

Gambar 2 dan Gambar 3 merupakan hasil plot grafik keadaan roda gigi normal pada 1 HTF, 3 HTF, 7 HTF dan 8 HTF sedangkan GMF terdapat pada 5 HTF yaitu pada frekuensi 781.3 Hz. Dengan menggunakan metode EEMD dapat dilihat bahwa peak lebih tinggi dibandingkan dengan sebelum menggunakan EEMD, contohnya perbedaan ketinggian peak pada $1 \mathrm{HTF}$ yaitu pada frekuensi $156.3 \mathrm{~Hz}$ pada grafik sebelum menggunakan EEMD terdapat pada amplitudo $0.004505 \mathrm{~g}$ sedangkan setelah EEMD 1x HTF memiliki amplitudo sebesar 0.01266g.

\subsubsection{Analisis FFT pada kondisi aus}

Sinyal FFT pada kondisi roda gigi yang mengalami keausan memiliki spektrum getaran yang berbeda. Dapat diamati ketika roda gigi mengalami keausan, GMF maupun HTF yang terdapat pada frekuensi yang sama dengan roda gigi pada kondisi nomal maka terlihat peningkatan amplitudo seperti yang ditunjukkan pada Gambar 4 dan Gambar 5 sebagai berikut

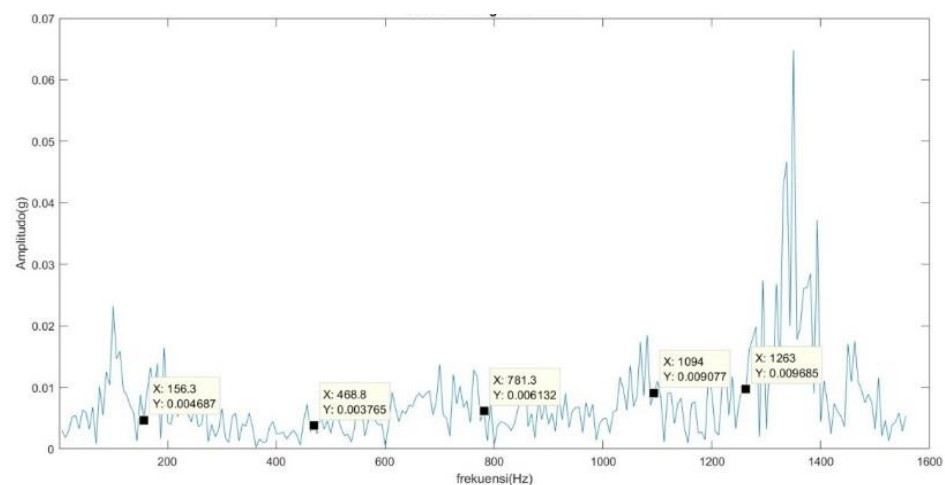

Gambar 4. FFT kondisi aus sebelum EEMD 


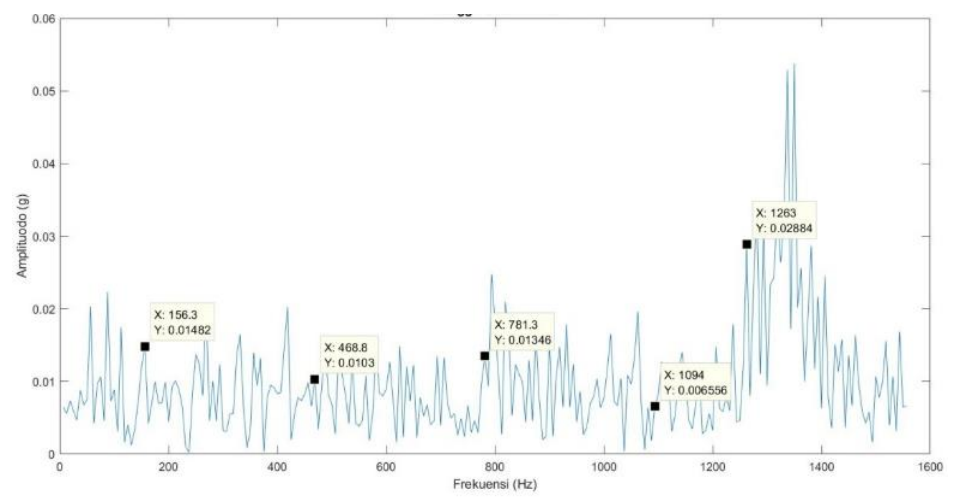

Gambar 5. FFT kondisi aus sesudah EEMD

\subsubsection{Analisis FFT pada kondisi patah poros}

Pada roda gigi kondisi patah poros, dapat terlihat bahwa frekuensi side band yang muncul disekitar $1 \mathrm{HTF}, 3 \mathrm{HTF}$, 7HTF, 8 HTF serta pada sekitar GMF lebih banyak jika dibandingkan dengan roda gigi kondisi normal maupun roda gigi kondisi aus. Pada frekuensi yang sama amplitudo yang dihasilkan dari roda kondisi patah porospun relatif lebih tinggi jika dibandingkan dengan kondisi roda gigi normal maupun kondisi roda gigi aus.

Tingginya amplitudo yang dihasilkan serta banyaknya side band yang muncul pada kondisi patah poros dapat kita lihat pada Gambar 6 dan Gambar 7 sebagai berikut

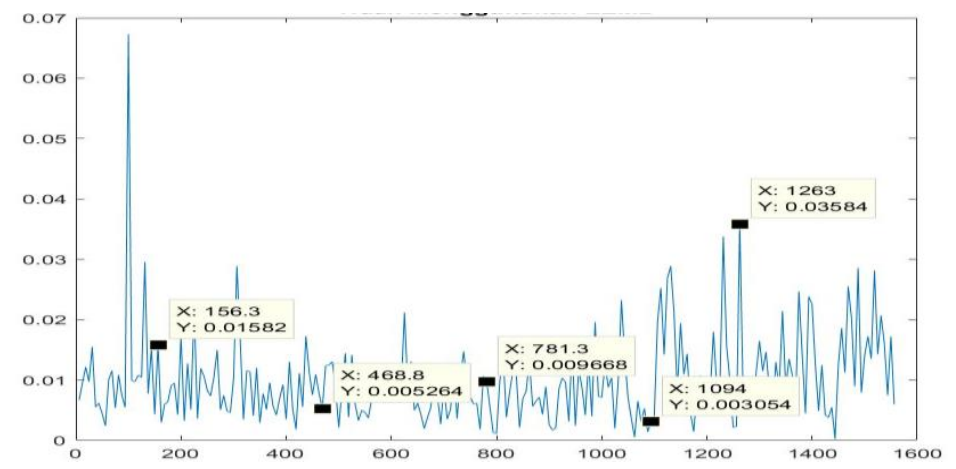

Gambar 6. FFT kondisi patah poros sebelum EEMD

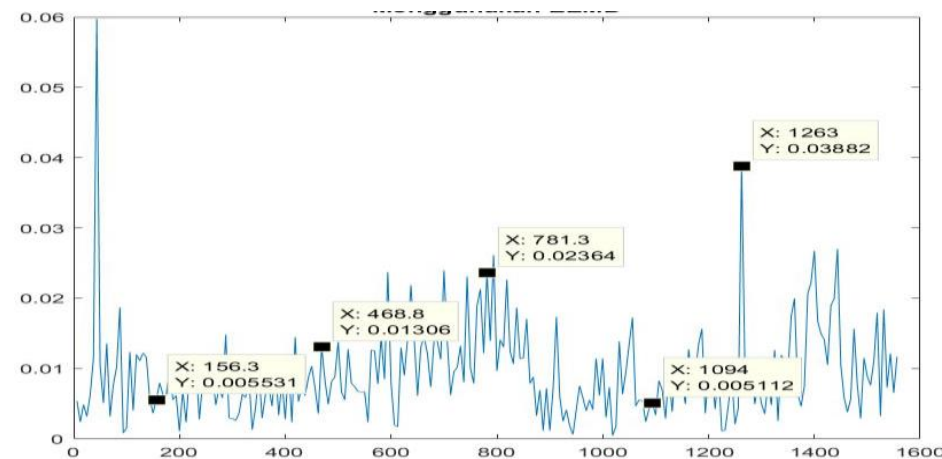

Gambar 7. FFT kondisi patah poros seteah menggunakan EEMD

3.2. Fitur Ekstraksi

Di bawah ini merupakan data hasil ekstraksi fitur RMS, kurtosis (k), crest factor pada data kondisi idle, normal, keausan, dan kerusakan pada poros. Data yang akan di olah yaitu RMS pada kondisi original lalu IMF 1, IMF 2, IMF 3, IMF 4, IMF 5, dan IMF 6.

Tabel 1. Nilai RMS pada IMF 1-6

\begin{tabular}{ccccccc}
\hline & IMF 1 & IMF 2 & IMF 3 & IMF 4 & IMF 5 \\
\hline DATA 1 & $2.8846 \mathrm{e}+03$ & $2.8850 \mathrm{e}+03$ & $2.8846 \mathrm{e}+03$ & $2.8856 \mathrm{e}+03$ & $2.8860 \mathrm{e}+03$ & $2.8863 \mathrm{e}+03$ \\
DATA 2 & $2.9692 \mathrm{e}+03$ & $2.9695 \mathrm{e}+03$ & $2.9699 \mathrm{e}+03$ & $2.9702 \mathrm{e}+03$ & $2.9705 \mathrm{e}+03$ & $2.9708 \mathrm{e}+03$ \\
DATA 3 & $2.8970 \mathrm{e}+03$ & $2.8973 \mathrm{e}+03$ & $2.8976 \mathrm{e}+03$ & $2.8980 \mathrm{e}+03$ & $2.8983 \mathrm{e}+03$ \\
DATA 4 & $2.8952 \mathrm{e}+03$ & $2.8956 \mathrm{e}+03$ & $2.8959 \mathrm{e}+03$ & $2.8962 \mathrm{e}+03$ & $2.8965 \mathrm{e}+03$ & $2.8969 \mathrm{e}+03$ \\
DATA 5 & $2.9751 \mathrm{e}+03$ & $2.9754 \mathrm{e}+03$ & $2.9757 \mathrm{e}+03$ & $2.9761 \mathrm{e}+03$ & $2.9764 \mathrm{e}+03$ & $2.9767 \mathrm{e}+03$ \\
\hline
\end{tabular}




\begin{tabular}{ccccccc}
\hline DATA 6 & $3.3613 \mathrm{e}+03$ & $3.3616 \mathrm{e}+03$ & $3.3619 \mathrm{e}+03$ & $3.3622 \mathrm{e}+03$ & $3.3625 \mathrm{e}+03$ & $3.3628 \mathrm{e}+03$ \\
DATA 7 & $3.4030 \mathrm{e}+03$ & $3.4033 \mathrm{e}+03$ & $3.4036 \mathrm{e}+03$ & $3.4039 \mathrm{e}+03$ & $3.4041 \mathrm{e}+03$ & $3.4044 \mathrm{e}+03$ \\
DATA 8 & $3.4262 \mathrm{e}+03$ & $3.4265 \mathrm{e}+03$ & $3.4267 \mathrm{e}+03$ & $3.4270 \mathrm{e}+03$ & $3.4273 \mathrm{e}+03$ & $3.4276 \mathrm{e}+03$ \\
DATA 9 & $3.6680 \mathrm{e}+03$ & $3.6682 \mathrm{e}+03$ & $3.6685 \mathrm{e}+03$ & $3.6687 \mathrm{e}+03$ & $3.6690 \mathrm{e}+03$ & $3.6692 \mathrm{e}+03$ \\
DATA 10 & $3.4859 \mathrm{e}+03$ & $3.4862 \mathrm{e}+03$ & $3.4865 \mathrm{e}+03$ & $3.4867 \mathrm{e}+03$ & $3.4870 \mathrm{e}+03$ & $3.4873 \mathrm{e}+03$ \\
DATA 11 & $3.4784 \mathrm{e}+03$ & $3.4787 \mathrm{e}+03$ & $3.4790 \mathrm{e}+03$ & $3.4792 \mathrm{e}+03$ & $3.4795 \mathrm{e}+03$ & $3.4798 \mathrm{e}+03$ \\
\hline
\end{tabular}

Tabel 1 merupakan data RMS yang didapatkan dari 11 percobaan, dimana data getaran yang di dapat dari tiap percobannya diolah menggunakan metode EEMD kemudian menghasilkan 6 IMF. Data yang diperoleh kemudian di plot sehingga menghasilkan grafik seperti yang ditunjukan pada Gambar 11 sebagai berikut:

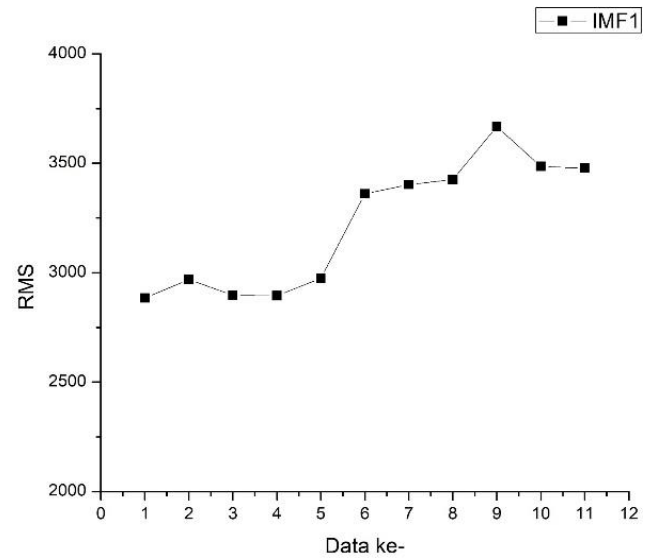

Gambar 8. Grafik fitur RMS untuk IMF 1

Gambar 8 merupakan hasil plot grafik yang datanya merupakan data IMF 1 dari tiap percobaan, dari Gambar 8 dapat kita lihat bahwa nilai RMS yang dihasilkan dari percobaan ke 1 sampe ke 11 hasilnya relatif naik hal ini dikarenakan adanya pengaruh waktu pengoperasian roda gigi terhadap besar getaran yang dihasilkan.

Tabel 2. Nilai kurtosis pada IMF 1-6

\begin{tabular}{lllllll}
\hline & IMF 1 & IMF 2 & IMF 3 & IMF 4 & IMF 5 & IMF 6 \\
\hline DATA 1 & 5.1172 & 5.1166 & 5.1160 & 5.1155 & 5.1148 & 5.1142 \\
DATA 2 & 5.3961 & 5.3954 & 5.3947 & 5.3940 & 5.3933 & 5.3926 \\
DATA 3 & 5.5157 & 5.5150 & 5.5142 & 5.5134 & 5.5127 & 5.5120 \\
DATA 4 & 5.4784 & 5.4777 & 5.4769 & 5.4760 & 5.4752 & 5.4743 \\
DATA 5 & 5.5841 & 5.5834 & 5.5827 & 5.5819 & 5.5810 & 5.5802 \\
DATA 6 & 6.3215 & 6.3205 & 6.3195 & 6.3185 & 6.3175 & 6.3165 \\
DATA 7 & 6.4792 & 6.4781 & 6.4770 & 6.4759 & 6.4747 & 6.4735 \\
DATA 8 & 6.4830 & 6.4820 & 6.4809 & 6.4798 & 6.4787 & 6.4777 \\
DATA 9 & 9.2869 & 9.2855 & 9.2840 & 9.2825 & 9.2814 & 9.2800 \\
DATA 10 & 6.8008 & 6.8000 & 6.7991 & 6.7983 & 6.7974 & 6.7966 \\
DATA 11 & 6.5069 & 6.5058 & 6.5047 & 6.5036 & 6.5025 & 6.514 \\
\hline
\end{tabular}

Tabel 2 merupakan data kurtosis yang didapatkan dari 11 kali pengambilan data getaran yang kemudian diolah dengan metode EEMD, kurtosis pada IMF pertama pada setiap datanya kemudian diplot dan menghasilkan grafik sebagai berikut:

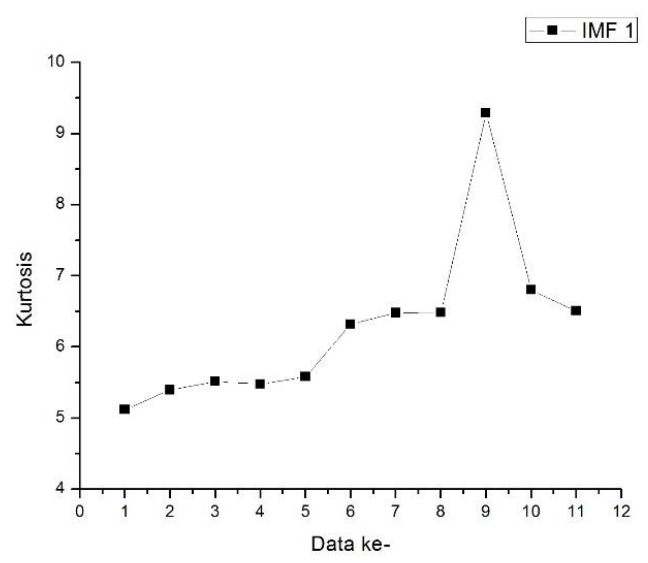

Gambar 9. Grafik plot kurtosis 
Pada Gambar 12 dapat dilihat bahwa fitur kurtosis cenderung meningkat pada tiap pengambilan datanya, dan puncak tertingginya pada pengujian data ke 9 . Hal ini disebabkan karena data ke 9 merupakan data yang diambil ketika roda gigi mengalami patah poros.

\section{Kesimpulan}

Sebagai kesimpulan hasil penelitian tentang deteksi kerusakan roda gigi menggunakan metode FFT dan metode ensembel dekomposisi modus empiris (EEMD) adalah sebagai berikut: 1.Kondisi roda gigi pada normal, aus dan patah poros dapat dideteksi dengan menggunakan metode ensemble dekomposisi modus empiris dengan melihat HTF, GMF serta kemunculan sideband; 2.Karakteristik sinyal getaran yang terjadi pada masing-masing kondisi, seperti pada patah poros dapat dilihat dari perbedaan yang cukup jelas pada plot FFT non-EEMD dengan metode EEMD; 3.Ekstraksi fitur sinyal getaran dapat dilakukan dengan menggunakan beberapa parameter statistik, antara lain: RMS, kurtosis. Pada fitur ekstraksi terlihat bahwa baik RMS maupun kurtosis keduanya menunjukan nilai yang relatif tinggi pada pengambilan data ke-9, hal ini disebabkan data ke-9 merupakan data roda gigi yang mengalami kondisi patah poros.

\section{Referensi}

[1] Dhillon, B.S., 2006, Maintanability, Maintenance, and Realibility for Engineers. Taylor and Francis Group. New York: LLC

[2] Wu, Z., Huang, N.E., 2004, Ensemble Empirical Mode Decomposition: a Derau Assisted Data Analysis Method. Centre for Ocean-Land-Atmosphere Studies. Technical Report, vol. 193, p. 51.

[3] AES2-2012 standard, Annex B (Informative): Crest Factor, pp. 17-20.

[4] Bird, J., Basic Engineering Mathematic. Elsever. 2005.

[5] Penter, A., Practical gear fault diagnosis uing vibration-based methods, COMADEM 89 International(1989)

[6] Brigham, E.O., 1997, The Fast Fourier Transform and Its Applications, Prentice-Hall International Inc., New York.

[7] Brown, S., 2008. "Measures of Shape: Skewness and Kurtosis, Oak Road Systems.

[8] Crowford, Arthur R., Crowford S., 1992, "The Simplified Handbook of Vibration Analysis, Volume 1, SCI, Knoxville.

[9] Dybala, J., Zimroz R., 2014, Rolling Bearing Diagnosing Based on Empirical Mode Decompotition of Machine Vibration Signal, Science Direct, Warsaw University of Technology, Poland.

[10] Howieson, D., 2003, Vibration Monitoring: Envelope Signal Processing, San Diego, U.S.A.

[11] Mollasalehi, E. Wood, D. Sun, Q., 2016. Bearing fault diagnosis using empirical mode decomposition based order tracking - wind turbine generator application, University of Calgary.

[12] Huang, N.E., Shen, Z., Long, S.R., dkk., 1998, The empirical mode decomposition and Hilbert spectrum for nonlinear and non-stationary time series analysis, Proceeding of the Royal Society A, vol. 454, no. 1971, p. 903995. 